What makes a smart village smart? A review of the literature

\begin{tabular}{|r|l|}
\hline Journal: & Transforming Government: People, Process and Policy \\
\hline Manuscript ID & TG-07-2021-0126.R2 \\
\hline Manuscript Type: & Literature review \\
\hline Keywords: & smart villages, rural development, digitisation, ICT4D, smart cities \\
\hline \multicolumn{2}{|l}{} \\
\end{tabular}




\section{Article Title Page}

What makes a smart village smart? A review of the literature

\section{Author Details:}

\section{Paolo Gerli}

The Business School, Edinburgh Napier University, Edinburgh, UK

Julio Navio Marco

Universidad Nacional de Educación a Distancia, Madrid, Spain

Jason Whalley

Newcastle Business School, Northumbria University, Newcastle, UK

Institut Mines-Télècom Business School, Evry, France

Corresponding author: Paolo Gerli

p.gerli@napier.ac.uk

NOTE: affiliations should appear as the following: Department (if applicable); Institution; City; State (US only); Country. No further information or detail should be included

\section{Acknowledgments (if applicable):}

A previous version of this paper was presented at International Telecommunications Society Biennial Conference in July 2021.

\section{Biographical Details (if applicable):}

[Author 1 bio]

[Author 2 bio]

[Author 3 bio]

[Author 4 bio]

\section{Structured Abstract:}

Purpose - Smart villages have lately attracted considerable attention, but what does the term mean? In this paper we review the literature to highlight its ambiguous nature and identify main theoretical and practical aspects to be further explored in the conceptualisation and implementation of these initiatives.

Design/methodology/approach - The analysis draws upon a review of 69 references from the grey and academic literature on smart villages, identified through a systematic search of academic databases and snowball sampling.

Findings - Our review highlights how the definition and characterisation of smart villages is shaped by disciplinary backgrounds and geographical context. Our analysis also demonstrates how smart villages are often viewed as being the opposite of smart cities, with limited engagement in the literature with other debates around rurality, the development of appropriate (digital) skills and the development of smart sustainable initiatives. It is only through engaging with these other debates that a better understanding of the term will emerge.

Originality - This is the first paper to conduct a systematic literature review on smart villages, taking into account multiple disciplinary, technological and geographical contexts. In addition to identifying the main trends in the conceptualisations and design of these initiatives, this paper contributes to the academic debate on smart rural development and provide useful recommendations to both policymakers and practitioners.

Keywords: smart villages; rural development; smart specialisation strategy; digitisation; ICT4D.

Article Classification: Literature review

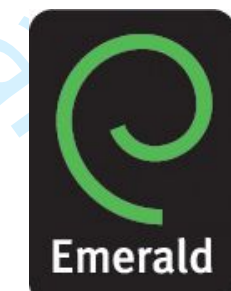




\section{Type header information here}

For internal production use only

\section{Running Heads:}

10 


\title{
What makes a smart village smart? A review of the literature
}

2

3

4

5

6

\begin{abstract}
Purpose - Smart villages have lately attracted considerable attention, but what does the term mean? This literature review explores its ambiguous nature and identifies main theoretical and practical aspects to be further explored in the conceptualisation and implementation of these initiatives.
\end{abstract}

Design/methodology/approach - The analysis draws upon a review of 79 references from the grey and academic literature on smart villages, identified through a systematic search of academic databases and snowball sampling.

Findings - Our review highlights how the definition and characterisation of smart villages is currently shaped by disciplinary backgrounds and geographical contexts. Smart villages are often viewed as the rural version of smart cities or an innovative model for rural development, but there has been little engagement in the literature with other debates around rurality and sustainable development. It is only through engaging with these other debates that a better understanding of the term will emerge.

Originality - This is the first paper to conduct a systematic review on smart villages. In addition to identifying the main trends in the conceptualisations and design of these initiatives, this paper contributes to the academic debate on smart rural development and provide useful recommendations to both policymakers and practitioners.

Keywords: smart villages; rural development; smart specialisation strategy; digitisation; ICT4D. 


\section{Introduction}

27 Smart cities (SCs) have been promoted and analysed for more than two decades, smart 28 villages (SVs) only recently have attracted the interest of policymakers and researchers 29 alike. These initiatives are being implemented in both developed and developing 30 countries as part of national and international programmes for rural development 31 (European Commission, 2016; European Commission, 2017; CGIAR, n.d.). Researchers 32 with an engineering or technical background have often contributed to these projects, with 33 the development of smart artefacts purposely designed for rural users (Larsen and Estes, 34 2019; Ouédraogo et al., 2019). More recently social scientists have also engaged with 35 SVs, focusing on their management and impact upon rural communities (Pělucha, 2020; 36 Despotović, 2020).

To date a variety of case studies have been analysed, highlighting the 38 heterogeneity of models and approaches adopted worldwide for the implementation of 39 these initiatives. Such a heterogeneity arguably reveals the composite nature of SVs, but 40 it also suggests that the concept itself has yet to be clearly delineated (Zavratnik et al., 41 2018). Therefore, this paper proposes a systematic review of the academic and grey 42 literature with the aim of exploring how the concept and practice of SVs change across 43 different geographic contexts and disciplinary areas. By reviewing the experiences so far 44 analysed in the literature, this paper will clarify the composite nature of SVs and map 45 how this relates to the growing debate on the implementation of smart technologies in 46 non-urban contexts.

With this in mind, the analysis is structured as follows: Section 2 summarises the 48 current debate on the expansion of smart cities (SCs) beyond urban boundaries. Section 493 describes the methodology applied to systematically review the literature, whose 
50 findings are presented in Section 4 and discussed in Section 5. Section 6 provides 51 concluding remarks, including recommendations for researchers and policymakers.

\section{Smart cities beyond cities: the state of the art}

54 While SCs have been researched for more than two decades (Palomo-Navarro and Navio 55 Marco, 2018), only recently have scholars started to explore whether and how these 56 initiatives can be applied to other geographic contexts. Several constructs - such as those 57 of 'smart village', 'smart region', 'smart territory' and 'smart island' - have been proposed to describe the expansion of SCs models beyond urban boundaries (GobinRahimbux et al., 2020; Sutriadi, 2018; Navio Marco et al., 2020).

Consistent with what has been observed in the SC literature (Mora et al., 2017), earlier research on SVs and similar constructs primarily focused on their technological aspects (Somwanshi et al., 2016; Anderson et al, 2017). Later studies have also investigated how these initiatives can effectively benefit rural communities (Acosta et al., 2021; Philips and Williams; 2019). As noted by Zavratnik et al. (2018), most research in this area remains case-dependant rather than theoretically grounded.

In fact, fewer attempts have been made to theorise smart initiatives in a non-urban

67 context. Cowie et al. (2019) framed them as an example of networked rural development, combining exogenous and endogenous actors and resources. Naldi et al. (2015), instead,

69 linked 'smart rural development' to the concepts of sustainable development and smart 70 specialisation, a novel paradigm advocating a place-based approach to innovation policies 71 (McCann and Ortega-Argiles, 2013). Sustainability has also become a central area of 72 inquiry for SCs researchers, which are increasingly advocating the creation of ‘sustainable smart cities' (Ahvenniemi et al., 2017). 
More generally, research on SVs and similar constructs tend to overlook the fact that the implementation and impact of digital technologies differ widely between rural and urban areas (Gerli and Whalley, 2021; Freeman and Park, 2015). The need to overcome these normative biases in the literature on SCs and SVs has been highlighted by Visvizi and Lytras (2018b), who stressed the importance of analysing these initiatives in relation to the geographic contexts they are embedded in. Indeed, even those researchers focusing on urban projects are increasingly recognising the influence of the local contexts, highlighting how the implementation of SCs varies between large and small cities (Lopes and Oliveira, 2017; Sokolov et al., 2019).

\section{Research methodology}

In March 2021, a systematic search of major academic databases was conducted (GobinRahimbux et al., 2020), following the steps detailed in Table 1. Using 'smart' and 'village' as keywords, the search returned 156 academic outputs. Of these, 71 references were excluded, because their titles or abstracts did not focus on SVs or were in a language different from English. Once duplications were also eliminated, the search yielded a total of 70 outputs. Of these, 17 were discarded after reading their full text, which described applications for SVs without defining or explaining what SVs are. Snowball sampling, however, led to the inclusion of further 13 academic references. An additional 13 references were identified by repeating the search in June 2021 and November 2021. Hence, the review covered 79 references in total.

NVIVO was used to structure the review of the literature applying eclectic coding, a method for qualitative research that combines different coding methods (Saldana, 2016). As detailed in Table 2, descriptive coding was employed to categorise explicit and 
implicit definitions of SVs as well as the frameworks and quotes describing the components of these initiatives. Both definitions and descriptions were then thematically analysed. Consistent with the review in Section 2, the analysis of the definitions explored how the conceptualisation of SVs relate to the literature on SCs and to existing theories of rural and smart development. It also highlighted two additional themes: the geographic scope of SVs and the meaning of smartness. The analysis of the frameworks and technology, human capital, physical resources, services, and governance. case studies. The latter were mainly located in Poland (11 references), India or Malaysia 122 (3 studies each). 


\subsection{Explicit definitions of smart villages}

125

126

127

128

129

130

131

132

133

134

135

136

137

138

139

140

141

142

143

144

145

146

147

As detailed in Table 3, SVs were explicitly defined in nine cases. Three definitions were coined by international organisations promoting these initiatives: the ENRD, the Consultative Group for International Agricultural Research (CGIAR) and IEEE. Five were developed in academic publications, with the remaining one being proposed by the representative of a company.

\section{[Insert Table 3 about here]}

The definitions reveal the variety of technological and socio-economic aspects that SVs can encompass. For example, CGIAR focuses on climate-smart technologies and agriculture, while IEEE describes SVs as the combination of renewable energy, community-based education, and entrepreneurial opportunities. The role of communities and opportunities is central to ENRD's definition, which, perhaps surprisingly, does not refer to any specific technology. Conversely, academic definitions explicitly link SVs to the application of ICT and data technologies in a rural environment.

Among those works that did not develop their own definition, most used those coined by the ENRD, IEEE and the CGIAR programme. Five scholars referred to the definition by Viswanadham and Vedula (2010), which was the only one coined by academics to be cited in other works. Some researchers highlighted how the literature still lacks a unanimous definition of SVs, with the existing conceptualisations being largely shaped by the heterogeneous contexts wherein these initiatives have been designed and implemented (Komorowsky and Stanny., 2020; Zavriatnik et al., 2020). 


\subsection{Definitions of village}

Interestingly, none of the definitions in Table 3 describe what 'village' means. In fact, only eight references explicitly addressed what a village is, and the conceptual and geographic boundaries of this term are far from being clear-cut. Slee (2019) and Zavriatnik et al. (2020) framed villages as 'physical communities' or 'small settlements', while Aggarwal et al. (2018) and Wollenberg et al. (2018) suggested an overlap with local administrative units. Visvizi et al. (2019), in contrast, described a village as a microcosm and a community to highlight its difference from other constructs, such as 'rural areas' and 'countryside', that are seen as de-personalised.

Whereas scholars tended to agree on the limited size of villages (Despotovic et al., 2020; Zavriatnik et al., 2020), it has been highlighted that the scale of SVs is variable and context-dependant (Aggarwal et al., 2018; Philip and Williams, 2019). Some even suggested that SVs should not be limited to a single village but rather integrate neighbouring communities together (Bielska et al., 2021; Dobrota et al., 2020).

\subsection{Definitions of smart}

The term 'smart' was explicitly defined in 16 references. In most cases, it was associated with innovation or digital technologies (Pělucha, 2020; Philip and Williams, 2019; Slee, 2019). Some authors though contested this view, claiming that SVs do not necessarily require the use of advanced technologies (Shuldiner, 2020; Wolski, 2019), but rather rely on the collective intelligence of rural communities and their collaboration with multiple stakeholders (Zavratnik et al., 2020; Bielska et al., 2021). Murty and Shankar (2020) concluded that ICT in SVs are solely relevant to the achievement of human development, and, in their perspective, this represents a major difference between SVs and SCs.

A relationship between smart and sustainable development was also 
173 acknowledged. Adamowicz (2020) and Zavratink et al. (2018) described smart

174 development as a component of sustainable development, explicitly referring to the

175 sustainable development goals set by the United Nations. Chanak and Banerjee (2021)

176 presented smartness and sustainability as interrelated concepts that both contribute to

177 improving quality of life, equality, and other indicators of socio-economic progress.

\subsection{The relationship between smart villages and smart cities}

180

The review clearly highlighted how scholars tend to have conflicting views on the

relationship between SCs and SVs. Most viewed the latter as the rural equivalent of SCs

(Mishbah et al. 2018; Holmes et al., 2015; Ballina, 2020) or their complement in a rural

setting (Dobrota et al., 2020). Others, in contrast, conceived SVs as ontologically distinct

from SCs (Ella et al., 2018; Visvizi and Lytras, 2018a). SVs are described as more

community-oriented than SCs (Budziewicz-Guzlecka, 2019) and less focused on digital

technologies (Fennell et al., 2018, Murty et al., 2020). Consistently, SVs and SCs are

expected to require different technological solutions and business models (Katara, 2016;

Mohanty, 2021).

\subsection{The relationship between smart villages and rural development}

Regardless of the technologies involved in SVs, scholars agreed in conceiving them as place-based and bottom-up initiatives (Aggarwal et al., 2018; Fennell et al., 2018). In both developed and developing countries, their implementation was described as a territorially-embedded process addressing the needs of a given territory (Bielska et al., 2021; Nieto et al., 2019) and leveraging its potential and resources (Srivatsa, 2015; Adamowicz et al., 2021). 
198 development, yet this theory was only explicitly referred to in Guzal-Dec et al. (2019); 199 and Malek and Tahir (2017). Slee (2019), instead, linked SVs to the emerging literature 200 on smart specialisation strategies. Overall, the review confirmed that the current 201 conceptualisations of SVs lack a clear and robust theoretical underpinning.

202

203

\subsection{The components of smart villages}

204

The review identified 11 papers developing descriptive frameworks and 22 papers discussing the components of SVs. The analysis of these references led to the identification of five themes (technology, human capital, physical resources, services, and governance), representing the key constituents of these initiatives.

Among the technologies, broadband and ICT were emphasised as a prerequisite

for the establishment and development of SVs in Europe (Dobrota et al. 2020; Doyle et al., 2021). The role of ICT was also acknowledged as crucial for the SVs implemented in al., 2018).

However, some authors underlined that the opportunities deriving from these

SVs were also described as relying on physical resources - such as water, land in developing countries (Viswanadham and Vedula, 2010; Zhang and Zhang, 2020). 
223 Renewable energy, though, was also mentioned as a component of SVs in Europe

224 (Watson, 2019).

225

226

227

228

229

230

231

232

233

234

235

236

237

238

239

240

241

242

243

244

245

246

247

Similarly, the services that SVs provide differ depending on the context where these initiatives take place. The literature described the SVs implemented in Africa, Asia and Latin America as focusing on advanced practices for agriculture (Adesipo et al., 2020; Aggarwal et al., 2018) and the enhancement of public services such as health and education (Aziiza and Susanto, 2020; Malek and Tahir, 2017). The role of agriculture was debated by European scholars too: according to Pělucha (2020), SVs should go beyond smart agriculture, whose centrality was, instead, defended by Bisaga (2019). However, SVs in Europe were mostly described as providing innovative services (such as smart tourism, e-healthcare and smart mobility), combining ICT with social entrepreneurship (Slee, 2019; Ballina, 2020).

With regard to the governance of SVs, the participation of citizens recurred as a distinctive element in both developed and developing countries (Davidenko et al., 2018; Katara, 2016), differentiating these initiatives from SCs (Harakal'ova, 2018). Some scholars also remarked the role played by institutions (Santhiyakumari et al., 2016; Fennell et al., 2018), without explaining what institutions they referred to. Likewise, researchers agreed on the need for policies and strategies to guide the realisation of SVs (Slee, 2019; Aggarwal et al., 2018; Zhang and Zhang, 2020), without clarifying at what level such policies and strategies should be defined.

\section{Discussion}

Our review confirmed that the concept of a 'smart village' remains primarily defined by its practice. As a result, a universal definition or shared conceptualisations of SVs does not exist. Even the nature and scope of these initiatives are unsettled, as the notions of 
248 'smart' and 'village' still lack a clear definition.

249 Despite this heterogeneity, two major trends can be recognised in the 250 conceptualisations of SVs. In European debates, they are presented as community-led 251 projects leveraging smart technologies and social entrepreneurship to develop innovative 252 services that are expected to offset the decline of rural communities. In the literature 253 focusing on emerging economies, the role of ICT is less predominant and SVs are seen 254 as leveraging a wider array of technologies and resources to enhance the provision of essential services and innovate traditional economic activities.

These different models arguably reflect the heterogeneous levels of infrastructural

257 and institutional development characterising rural communities, but also evoke different 258 visions on rural development. In the European debate, SVs are expected to innovate and regenerate the rural economy by introducing new solutions that may eventually replace existing services. Consistently, they are seen as pioneering new models of rural development, where ICT is leveraged by rural communities to overcome their traditional reliance on agricultural activities and subsidised public services.

Conversely, researchers affiliated to Asian, African and Latin-American research institutions describe SVs as empowering rural communities and supporting their sustainable development, by tackling both environmental challenges and social issues within rural regions. In their conceptualisation, SVs are less focused on ICT but rather engage with a wider array of technological, human and natural resources in order to boost rather than replace existing models of rural development.

In line with Naldi et al. (2015), some European researchers have also recognised 270 a potential overlapping between smart and sustainable development in the context of SVs.

271 Social innovation indeed recurs as a key component of SVs in Europe, but environmental 272 issues are only incidentally mentioned. This highlights a possible gap in the 
273 conceptualisation and implementation of SVs in Europe, where the potential of these

274 initiatives for sustainable development seems largely unexplored or, at least, underresearched.

Overall, the review confirms that the term 'smart' may assume multiple meanings,

277 reflecting diverging views on the contribution of smart technologies to rural development.

278 Whereas the potential of ICT for SVs is widely recognised, some authors reject a techno279 centric view and rather emphasise the importance of human capital. This represents a clear definition. This is not surprising. Defining rurality has long proved challenging for researchers, as rural communities and regions differ quite widely from a demographic, spatial and socio-cultural perspective (Halfacree, 2016). These distinctions are also relevant in the context of smart rural development; for example, peripheral areas are examining the complex relationships that may exist between SCs and SVs (Zavratnik et al., 2018). Geographers have recently observed how rural spaces are increasingly enclosed in and connected with urban areas (Bedini and Bronzini, 2016). Future research 
298 should further consider these trends to fully capture the complex interplay existing 299 between cities and rural areas in the context of digitisation (Navio Marco et al., 2020). 300 Further attention should also be paid to middle-sized towns that, despite their role for 301 territorial cohesion (European Union, 2007), remains largely overlooked in the current 302 debate on SCs and SVs.

\section{Conclusions}

306

307

308

309

310

311

312

This review has highlighted that, despite its increasing popularity, the concept of SV remains ambiguous, being context-dependant rather than grounded on well-established theoretical constructs. Further research is, therefore, needed to establish a clear theoretical foundation for the conceptualisation of SVs. This will help clarify the scope and nature of SVs as well as their relationship with SCs and other relevant paradigms in regional and innovation studies. Furthermore, additional consideration should be given to the potential overlapping between smart and sustainable development in order to clarify how smartness affects social and environmental issues in a rural context.

From a practical perspective, our analysis helps practitioners and policymakers to identify and experiment with alternative configurations for the design and implementation of SVs. In particular, drawing upon the experiences developed in Africa and Asia, this review invites SVs in Europe to integrate environmental outcomes in their initiatives. This would also maximise their contribution to the EU agenda on the green and digital transitions (Slee, 2021).

The review also evidenced the plurality of endogenous and exogenous resources deemed as necessary for the implementation of SVs. Consequently, our paper helps the promoters of these initiatives identify gaps in the resources available at a local level and 
323 build partnerships with external actors to complement such gaps. Scholars could facilitate

324 this by conducting additional empirical studies that compare SVs across different 325 geographic settings.

326 Furthermore, this paper calls for further research on the scope for operational and 327 strategic collaborations between SCs and SVs. The two models are predominantly 328 conceived as either complements or alternatives, thereby overlooking the complex 329 relationships existing between cities and their surrounding rural. Overcoming such a 330 dichotomic view is a key priority to redirect research and policy debates towards 331 alternative theoretical and empirical models capable of maximising the potential of smart 332 technologies for local development and territorial cohesion (Navio-Marco et al., 2020).

333 Given the vague nature and boundaries of villages, our analysis reinforces the 334 importance of coordination and collaboration among rural communities in the 335 implementation of smart initiatives. Not only would this allow to leverage existing and 336 potential synergies. It would also prevent the emergence of new divides between smart 337 and unsmart villages (Slee, 2019), that could eventually undermine the potential of smart 338 initiatives for rural development and territorial cohesion. 


\section{References}

341 Acosta, M., Riley, S., Bonilla-Findji, O., Martinez-Baron, D., .., Chanana, N. (2021). 342 Exploring Women's Differentiated Access to Climate-Smart Agricultural Interventions in Selected Climate-Smart Villages of Latin America. Sustainability, Vol. 13 No. 19.

345

Adamowicz, M. (2021). The Potential for Innovative and Smart Rural Development in the Peripheral Regions of Eastern Poland. Agriculture, Vol. 11 No. 3, 188.

Adamowicz, M., and Zwolińska-Ligaj, M. (2020). "The "Smart Village" as a Way to Achieve Sustainable Development in Rural Areas of Poland". Sustainability, $12(16), 6503$.

Adesipo, A., Fadeyi, O., Kuca, K., ..., Adenola, M. (2020). "Smart and Climate-Smart Agricultural Trends as Core Aspects of Smart Village Functions", Sensors, Vo. 20 No. 21, 5977.

Aggarwal, P.K., Jarvis, A., Campbell, B. M., .., Yen, B.T. (2018). “The climate-smart village approach: framework of an integrative strategy for scaling up adaptation options in agriculture", Ecology and Society, Vol. 23 No. 1, p. 14.

Anderson, A., Loomba, P., Orajaka, I., ..., Larsen, R. (2017). "Empowering smart communities: Electrification, education, and sustainable entrepreneurship in IEEE smart village initiatives". IEEE Electrification Magazine, Vol. 5 No. 2, pp. 6-16.

Ahvenniemi, H., Huovila, A., Pinto-Seppä, I., Airaksinen, M. (2017). "What are the differences between sustainable and smart cities?", Cities, Vol. 60, pp. 234-245.

Aziiza, A.A., and Susanto, T.D. (2020). “The Smart Village Model for Rural Area". Paper presented at $3^{\text {rd }}$ International Conference on Engineering Technology for Sustainable Development, 23-24 October 2019, Yogyakarta (Indonesia).

Ballina, F. J. (2020). "Is there rural smart tourism? A Spanish experience", Management Theory and Studies for Rural Business and Infrastructure Development. Vol. 42, No. 3, pp. 369-380.

Bielska, A., Stańczuk-Gałwiaczek, M., Sobolewska-Mikulska, K., Mroczkowski, R. (2021). "Implementation of the smart village concept based on selected spatial patterns - A case study of Mazowieckie Voivodeship in Poland", Land Use Policy, Vol. 104, 105366.

Bisaga, A. (2019). "Examining Sources of Farmers' Knowledge as a Premise Behind Realization of the Smart Village Conception. A Case Study of Opole Region". Krakowiak-Bal A., Vaverkova M. (eds). Infrastructure and Environment. Springer, Cham, pp. 313-320.

Budziewicz-Guzlecka, A. (2019). "Smart village as a direction for rural development". Proceedings of the 2019 International Conference "Economic Science for Rural Development", Vol. 52. 
CGIAR (n.d.). "Climate-smart village: the CCAFS model to improve the adaptive capacity of communities". Available at https://ccafs.cgiar.org/climate-smartvillages

Chanak, P., and Banerjee, I. (2021). "Internet-of-Things-Enabled SmartVillages: An Overview", IEEE Consumer Electronics Magazine, Vol. 10 No. 3, pp. 12-18.

Cowie, P., Townsend, L. and Salemink, K. (2020). "Smart rural futures: Will rural areas be left behind in the 4th industrial revolution?", Journal of Rural Studies, Vol. 79, pp. 169-176.

Davidenko, P., Menshikova, E., and Gorbenkova, E. (2020). "Smart settlements: the development concept in a new socio-economic and informatiologic conditions". IOP Conference Series: Materials Science and Engineering, Vol. 365 No. 2, 022050 .

Despotović, A., Joksimović, M., and Jovanović, M. (2020). "Demographic revitalization of Montenegrin rural areas through the smart village concept". Poljoprivreda $i$ Sumarstvo, Vol. 66, No. 4, pp. 125-138.

Dobrota, L.M., Simescu, L.M., and Turek-Rahoveanu, M.M. (2020). "Sustainability of rural areas through innovative actions". Economic Engineering in Agriculture and Rural Development, Vol. 20 No. 2, pp. 211-216.

Doyle, A., Hynes, W., and Purcell, S. M. (2021). "Building Resilient, Smart Communities in a Post-COVID Era: Insights from Ireland", International Journal of E-Planning Research, Vol. 10 No. 2, pp. 18-26.

Ella, S. and Andari, R.N. (2018). "Developing a Smart Village Model for Village Development in Indonesia", paper presented at International Conference on ICT for Smart Society, 10 ${ }^{\text {th }}-11^{\text {th }}$ October 2018, West Java (Indonesia).

European Commission. (2016). CORK 2.0 Declaration 2016 for a better life in rural areas. Brussels, Belgium.

European Commission. (2017). EU action for smart villages. Brussels, Belgium.

European Union (2007). Territorial Agenda of the European Union. Leipzig, Germany.

ENRD. (2018). "Smart villages: Revitalising rural services". EU Rural Review 26. Available at enrd.ec.europa.eu

Fennell, S., Kaur, P., Jhunjhunwala, A., Narayanan, D., ..., Singh, Y. (2018). "Examining linkages between Smart Villages and Smart Cities: Learning from rural youth accessing the internet in India", Telecommunications Policy, Vol. 42 No. 10, pp. 810-823.

Freeman, J. and Park, S. (2015). "Rural realities. Digital communication challenges for rural Australian local governments", Transforming Government: People, Process and Policy, Vol. 9 No. 4, pp. 465-479. 
415 Gerli, P., and Whalley, J. (2021). "Fibre to the countryside: A comparison of public and 416 community initiatives tackling the rural digital divide in the UK". Telecommunications Society, in press.

Gobin-Rahimbux, B., Cadersaib, Z., Chooramun, N., ..., Elaheeboccus, S. (2020), “A Council”, Transforming Government: People, Process and Policy, Vol. 14 No. 2, pp. 261-281.

Guzal-Dec, D., Zwolińska-Ligaj, M., \& Zbucki, Ł. (2019). "The potential of smart development of urban-rural communes in peripheral region (a case study of the Lublin Region, Poland)", Miscellanea Geographica, Vol. 23 No. 2, pp. 85-91.

Halfacree, K.H. (2016). "Locality and Social Representation: Space, Discourse and Alternative Definitions of the Rural". In Munton, R. (Ed.), The Rural. Critical Essays in Human Geography, UK: Routledge.

Holmes, J., Jones, B., and Heap, B. (2015). "Editorial: Smart villages". Science, Vol. 350 No. 6259 , p. 359.

IEEE Smart Village (n.d.). About IEEE Smart Village. Available at https://smartvillage.ieee.org/about-ieee-smart-village/

Katara, S.K. (2016). "Envisioning Smart Villages Through Information and Communication Technologies - A Framework for Implementation in India". In Chugunov, A.V., Bolgov, R., Kabanov, Y., Kampis, G. and Wimmer, M. (eds). Digital Transformation and Global Society, Springer, Cham.

Komorowski, Ł., and Stanny, M. (2020). "Smart Villages: Where Can They Happen?", Land, Vol. 9 No. 5, 151.

Larsen, R. S., and Estes, D. (2019). "IEEE smart village launches sunblazer iv and smart portable battery kits: Empowering remote communities", IEEE Systems, Man, and Cybernetics Magazine, Vol. 5 No. 3, pp.49-51.

Lopes, I.; and Oliveira, P. (2017). "Can a small city be considered a smart city?", Procedia Computer Science, Vol. 121, pp. 617-624.

Malek, J.A., and Tahir, Z. (2017). "Telecenters in the Development of the Smart Village Cybergogy for Multicultural Transformation". In Proceedings of the $1^{\text {st }}$ International Conference on Social Sciences Education, pp.159-166.

McCann, P., and Ortega-Argilés, R. (2013). "Smart Specialization, Regional Growth and Applications to European Union Cohesion Policy", Regional Studies, Vol. 49 No. 8, pp. 1291-1302.

Mishbah, M., Purwandari, B., and Sensuse, D. I. (2018). "Systematic review and metaanalysis of proposed smart village conceptual model: Objectives, strategies, dimensions, and foundations", in International Conference on Information Technology Systems and Innovation (ICITSI).

Mohanty, S. P. (2021). "Low-Cost Consumer Technology Can Help to Build Sustainable Smart Villages", IEEE Consumer Electronics Magazine, Vol. 10 No. 3, pp. 4-5. 
Mora, L., Bolici, R., and Deakin, M. (2017). "The first two decades of smart-city research: A bibliometric analysis", Journal of Urban Technology, Vol. 24 No. 1, pp. 3-27.

Murty, V. K., and Shankar, S. S. (2020). "Towards a Scalable Architecture for Smart Villages: The Discovery Phase”. Sustainability, Vol. 12 No. 18, 7580.

Naldi, L., Nilsson, P., Westlund, H., and Wix, S. (2015). "What is smart rural development?", Journal of Rural Studies, Vol. 40, pp. 90-101.

Navio Marco, J., Rodrigo-Moya, B., Gerli, P. (2020). "The rising importance of the 'Smart territory' concept: definition and implications", Land Use Policy, Vol. 99, 105003.

Nieto, E., and Brosei, P. (2019). "The Role of LEADER in Smart Villages: An Opportunity to Reconnect with Rural Communities". In Visvizi, A., Lytras, M.D. and Mudri, G. (Eds.). Smart Villages in the EU and Beyond. UK: Emerald Publishing, pp. 63-81.

Ouédraogo, M., Houessionon, P., Zougmoré, R. B., and Partey, S. T. (2019). “Uptake of climate-smart agricultural technologies and practices: Actual and potential adoption rates in the climate-smart village site of Mali”, Sustainability, Vol. 11 No. 17, 4710.

Palomo-Navarro, A., and Navio-Marco, J. (2018). "Smart city networks' governance: The Spanish smart city network case study", Telecommunications Policy, Vol. 42 No. 10, pp. 872-880.

Pělucha, M. (2020). "Smart Villages and Investments to Public Services and ICT Infrastructure: Case of the Czech Rural Development Program 2007-2013", European Countryside, Vol. 11 No. 4, pp. 584-598.

Pérez-delHoyo, R. and Mora, H. (2019). “Toward a New Sustainable Development Model for Smart Villages”. In Visvizi, A., Lytras, M.D. and Mudri, G. (Eds.). Smart Villages in the EU and Beyond. UK: Emerald Publishing, pp. 49-62

Philip, L., and Williams, F. (2019). "Healthy ageing in smart villages? Observations from the field”, European Countryside, Vol. 11 No. 4, pp. 616-633.

Puthal, D., Mohanty, S. P., Wilson, S., and Choppali, U. (2021). "Collaborative Edge Computing for Smart Villages”, IEEE Consumer Electronics Magazine, Vol. 10 No. 3, pp. 68-71.

Ram, S. K., Das, B. B., Mahapatra, K., ..., Choppali, U. (2021). "Energy Perspectives in IoT Driven Smart Villages and Smart Cities". IEEE Consumer Electronics Magazine, Vol. 10 No. 3, pp. 19-28.

Saldaña, J. (2014). The coding manual for qualitative researchers. US: Sage Publishing.

Santhiyakumari, N., Shenbagapriya, M., and Hemalatha, R. (2016). "A Novel Approach in Information and Communication Technology combined with traditional practices for Smart Villages", paper presented at IEEE $10^{\text {th }}$ Humanitarian Technology Conference, $21^{\text {st }}-23^{\text {rd }}$ December 2016, Dayalbagh (India). 
497

498

499

500

501

502

503

504

505

506

507

508

509

510

511

512

513

514

515

516

517

518

519

520

521

522

523

524

525

526

527

528

529

530

531

Shuldiner, A. (2020). "The Smart Village", IEEE Pervasive Computing, Vol. 19 No. 1, pp. 83-86.

Slee, B. (2019). "Delivering on the concept of smart villages-in search of an enabling theory", European Countryside, Vol. 11 No. 4, pp. 634-650.

Slee, B. (2021). Smart Villages and the European Green Deal: making the connections. Available at https://enrd.ec.europa.eu/

Sokolov, A., Veselitskaya, N., Carabias, V., and Yildirim, O. (2019). "Scenario-based identification of key factors for smart cities development policies", Technological Forecasting and Social Change, Vol. 148, 119729.

Somwanshi, R., Shindepatil, U., Tule, D., ..., Deshmukh, A. (2016). "Study and development of village as a smart village", International Journal of Scientific \& Engineering Research, Vol. 7 No. 6, pp. 395-408.

Srivatsa, P. (205). "Rural Urban Migration: Disturbing the Equilibrium between Smart Cities and Smart Villages", FIIB Business Review, Vol. 4 No. 3, pp. 3-10.

Sutriadi, R. (2018). "Defining smart city, smart region, smart village, and technopolis as an innovative concept in indonesia's urban and regional development themes to reach sustainability". In IOP Conference Series: Earth and Environmental Science, Vol. 202 No. 1, 012047.

Visvizi, A., Lytras, M. (2018a). "It's not a fad: Smart cities and smart villages research in European and global contexts", Sustainability, Vol. 10 No. 8, 2727.

Visvizi, A., Lytras, M. (2018b). "Rescaling and refocusing smart cities research: from mega cities to smart villages", Journal of Science and Technology Policy Management, Vol. 9 No. 2, pp. 134-145

Viswanadham, N. and Vedula, S. (2010). Design of Smart Villages. Indian School of Business, Hyderabad (India).

Watson, J.K.R. (2019), "Energy Diversification and Self-sustainable Smart Villages". In Visvizi, A., Lytras, M.D. and Mudri, G. (Eds.) Smart Villages in the EU and Beyond, UK: Emerald Publishing, pp. 99-109.

Wollenberg, E., Hansen, J., Aggarwal, P.K., ..., Ramirez-Villegas, J. (2018). "The climate-smart village approach: framework of an integrative strategy for scaling up adaptation options in agriculture", Ecology and Society, Vol. 23 No. 1, pp. 474-488.

Wolski, O., and Wójcik, M. (2019). "Smart villages revisited: Conceptual background and new challenges at the local level". In Visvizi, A., Lytras, M.D. and Mudri, G., Editors, Smart Villages in the EU and Beyond. UK: Emerald Publishing.

Zavratnik, V., Kos, A., and Stojmenova Duh, E. (2018). "Smart villages: Comprehensive Review of Initiatives and Practices", Sustainability, Vol. 10 No. 7, 2559.

Zavratnik, V., Podjed, D., Trilar, J., Hlebec, N., Kos, A., and Stojmenova Duh, E. (2020). "Sustainable and community-centred development of smart cities and villages", Sustainability, Vol. 12 No. 10, 3961. 
532 Zhang, X.J., and Zhang, Z.G. (2020). "How Do Smart Villages Become a Way to Achieve 533 Sustainable Development in Rural Areas? Smart Village Planning and Practices in China", Sustainability, Vol. 12 No. 24, 10510. 
Table 1 - Process and output of the systematic literature review

\begin{tabular}{|c|c|c|}
\hline Steps & Description & $\begin{array}{c}\text { Output } \\
\text { (n. of references) }\end{array}$ \\
\hline $\begin{array}{l}\text { 1) Identification and } \\
\text { selection of databases }\end{array}$ & \multicolumn{2}{|c|}{ Webofknowledge, EBSCO, ProQuest } \\
\hline 2) Keywords & \multicolumn{2}{|c|}{ TITLE-ABS-KEY (“smart village” OR “smart villages”) } \\
\hline 3) Search & $\begin{array}{l}\text { Webofknowledge: } 116 \text { references } \\
\text { EBSCO: } 16 \text { references } \\
\text { ProQuest: } 24 \text { references }\end{array}$ & 156 \\
\hline $\begin{array}{l}\text { 4) Review of titles and } \\
\text { abstracts }\end{array}$ & 71 references excluded & 85 \\
\hline 5) Automatic filters & 15 duplicates excluded & 70 \\
\hline 6) Full-text review & 17 references excluded & 53 \\
\hline 7) Snowball & 13 references added & 66 \\
\hline 8) Updated search & 13 references added & 79 \\
\hline
\end{tabular}

Table 2 - Summary of the coding analysis

\begin{tabular}{|l|c|}
\hline $\begin{array}{l}\text { Descriptive coding } \\
\text { (Number of references) }\end{array}$ & $\begin{array}{c}\text { Thematic coding } \\
\text { (Number of codes) }\end{array}$ \\
\hline \multirow{4}{*}{ Definitions } & In relation to rural and smart development \\
& In relation to SCs \\
Explicit (8) & $(25)$ \\
\cline { 2 - 2 } Implicit (40) & Meaning of smartness \\
& $(16)$ \\
\cline { 2 - 2 } & Geographic scope \\
& $(16)$ \\
\hline \multirow{4}{*}{ Descriptions } & Services \\
& $(43)$ \\
Comprehensive & Technology \\
frameworks (11) & $(30)$ \\
\cline { 2 - 2 } Discussion of single & Human capital \\
components (22) & $(30)$ \\
\cline { 2 - 2 } & Governance \\
& $(25)$ \\
\cline { 2 - 2 } & Natural resources \\
& $(18)$ \\
\hline
\end{tabular}


Table 3 - Definitions of SVs

\begin{tabular}{|l|l|}
\hline Source & Definition \\
\hline ENRD (2018) & $\begin{array}{l}\text { Smart villages are rural areas and communities which build on their existing strengths and assets as well } \\
\text { as on developing new opportunities }\end{array}$ \\
\hline CGIAR (n.d.) & $\begin{array}{l}\text { Climate-smart villages are an approach where CCAFS in partnership with rural communities and other } \\
\text { stakeholders tests and validates in an integrated manner, several agricultural interventions }\end{array}$ \\
\hline Fennell et al. (2018) & $\begin{array}{l}\text { The Smart Villages notion proposes as a bottom-up mechanism based on a data-generated understanding } \\
\text { of rural aspirations to generate economic growth, create wealth and sizeable demand for rural and } \\
\text { agricultural products, thereby enabling the shift from subsistence to a more diversified and sustainable } \\
\text { agriculture. }\end{array}$ \\
\hline Holmes (2018) & $\begin{array}{l}\text {..the "smart village," a rural analog of the "smart city" concept, in which access to sustainable energy, } \\
\text { together with modern information and communication technologies, enables holistic development, } \\
\text { including cultural changes in the provision of good education and healthcare; access to clean water, } \\
\text { sanitation, and nutrition; and the growth of social and industrial enterprises to boost incomes. }\end{array}$ \\
\hline IEEE Smart Village Initiative & $\begin{array}{l}\text { IEEE Smart Village has a unique approach to support the world's energy-impoverished communities by } \\
\text { providing a comprehensive solution combining renewable energy, community-based education, and } \\
\text { entrepreneurial opportunities. }\end{array}$ \\
\hline Pělucha (2020) & $\begin{array}{l}\text {..the concept SMART village is more complex and does not only cover the agricultural sector. On the } \\
\text { contrary, it is a wider use of the possibilities of the digital economy and relevant types of services, which } \\
\text { represents a very heterogeneous group of activities. }\end{array}$ \\
\hline Puthal et al. (2021) & $\begin{array}{l}\text { A village that uses information and communication technologies for advancing economic and social } \\
\text { development to make villages sustainable. }\end{array}$ \\
\hline Shuldiner (2018) & $\begin{array}{l}\text { I consider the "Smart Village," a smaller, less-dynamic, and more homogeneous place that may be, in } \\
\text { some ways, much smarter than any city. }\end{array}$ \\
\hline Viswanadham and Vedula (2010) & $\begin{array}{l}\text { We define a smart village as a bundle of services which are delivered to its residents and businesses in an } \\
\text { effective and efficient manner. }\end{array}$ \\
\hline
\end{tabular}

